\title{
Anesthésie chez le nouveau-né
}

Robert K. Crone, MD, Gregory K. Sorensen MD, Rosemary J. Orr MD

Les progrès du diagnostic prénatal, des soins obstétricaux et de la chirurgie néonatale ont augmenté la survie du nouveau-né à haut risque. Des interventions chirurgicales nouvelles et plus fréquentes ont accru l'implication de l'anesthésiste dans le soin périnatal de l'enfant à terme et prématuré. L'administration de l'anesthésie chez ces enfants compte parmi les défis les plus exigeants auxquels un anesthésiste peut avoir à faire face. Il comporte des difficultés évidentes associées à la petite taille des nouveau-nés, ce qui rend les tâches techniques de routine comme la ponction veineuse et l'intubation plus difficile. De plus, l'adaptation différente des nouveau-nés aux agents anesthésiques et autres substances, ajoute un stress additionnel à l'anesthésie de routine. Enfin, les aspects particuliers du développement de la physiologie du nouveau-né compliquent l'administration de l'anesthésie dans cette population et augmentent le risque de complications sérieuses telles l'hypoxémie, l'hypothermie, ainsi que les anomalies hydro-électrolytiques.

Les soins anesthésiques doivent être donnés à ces patients seulement par des anesthésistes complètement familiers avec les aspects particuliers de la physiologie et de la pharmacologie du nouveau-né en développement, et qui sont préparés aux défis techniques et aux complications possibles de l'anesthésie néonatale.

\section{Considérations physiologiques}

\section{Physiologie de transition chez le nouveau-né}

Une des différences les plus importantes entre le nouveauné et l'enfant plus vieux se retrouve dans la transition de la physiologie cardio-pulmonaire intra-utérine vers la physiologie adulte. Chez l'adulte, les ventricules pompent en série, avec le sang désaturé qui passe à travers le côté droit du cœur vers l'artère pulmonaire. Le sang saturé d'oxygène retourne ensuite des poumons vers le côte gauche du cœur et est remis en circulation en périphérie. La circulation foetale, par contre, est un circuit parallèle dans lequel il y a deux sites de mélange de sang saturé et désaturé, la fenêtre ovale et un canal artériel. La fermeture physiologique de ces deux sites tôt après la naissance amène la transition vers la circulation en série de l'adulte.'

Dans l'utérus, les échanges gazeux et la captation d'éléments nutritifs pour le foetus se fait par le placenta. Le sang oxygéné, saturé à $80 \%$, retourne du placenta vers la veine ombilicale et se rend vers la veine cave inférieure. A ce niveau le sang qui arrive du placenta se mélange avec celui qui revient des extrémités inférieures du fœtus, et ceci ramène la saturation à environ $70 \%$. Ce sang est de façon dominante dirigé vers l'oreillette gauche à travers la fenêtre ovale. La saturation du sang du côté gauche du cœur est de $65 \%$ après son mélange avec le sang de retour veineux des extrémités supérieures et du lit vasculaire pulmonaire exempt d'échanges gazeux. Une partie du sang qui revient du placenta se mélange avec celui qui arrive de la veine cave supérieure et entre dans le ventricule droit. Ceci amène une saturation de $55 \%$ au niveau du cœur droit. Le débit sanguin vers les poumons du fotus constitue à peine $7 \%$ du débit ventriculaire combiné, puisque les poumons ne participent pas aux échanges gazeux in utero. En fait, le lit pulmonaire fotal utilise l'oxygène disponible dans la circulation pulmonaire pour sa croissance et son métabolisme. La résistance vasculaire pulmonaire est très élevée chez le fœus. Ceci limite la circulation pulmonaire et amène le sang à passer directement dans l'artère pulmonaire principale à travers le canal artériel perméable jusque vers l'aorte descendante. Ce sang se mélange ensuite avec celui qui traverse l'arc aortique et perfuse la partie inférieure du corps et le placenta. La saturation de ce sang est d'environ $60 \%$. La déviation préférentielle et la différenciation dans le mélange du sang placentaire dans le cœur procure au myocarde et au cerveau du foetus en développement un sang plus riche en oxygène et en éléments nutritifs que celui qui perfuse la partie inférieure du corps. ${ }^{2}$

À la naissance, la circulation foetale est le siège de changements remarquables par la conversion de la physiologie cardio-pulmonaire fotale en une physiologie adulte; plusieurs de ces changements se produisent en quelques secondes. La première respiration néonatale s'accompagne d'une augmentation du débit sanguin vers les poumons par suite d'une diminution de la résistance vasculaire pulmonaire d'origine mécanique et hormonale, et les échanges gazeux néonataux commencent. L'augmentation du retour veineux pulmonaire augmente la pression dans l'oreillette gauche et produit une fermeture fonctionnelle de la fenêtre ovale. À peu près dans le même temps, le canal artériel commence à se contracter en réponse à une élévation de la pression partielle d'oxygène et par l'action de médiateurs endogènes qui incluent les prostaglandines. Quand le cordon ombilical est coupé et 
predictor of respiratory morbidity and mortality than pulmonary flow tests. ${ }^{12}$ A pre-operative Deco $>80$ per cent predicted, is associated with $\mathrm{a}<10$ per cent incidence of postoperative respiratory complications, while a Deco $<60$ per cent has a $>30$ per cent risk of respiratory complications.

Any of the common tests of lung function will give a falsely low estimate of postoperative function if there is an obstructing lesion in a major airway. For pneumonectomies it may be possible to revise downward the estimated risk on the basis of a bronchoscopy report or $\dot{V} / \mathrm{Q}$ scan. However, for resections of one lobe or less the $\dot{V} / \dot{Q}$ scan, ${ }^{13}$ bronchography or bronchoscopy " do not enhance the estimate of postoperative pulmonary function.

An arterial blood gas breathing air must always be obtained and any patient with an elevation of the $\mathrm{PaCO}_{2}$ is at high risk for even the most minor resection.

\section{Cardiovascular disease}

Cardiovascular complications occur as frequently as respiratory complications. Any ECG abnormality suggests an increased risk. Didolkar ${ }^{14}$ in 1974 found a 22 per cent mortality after pulmonary resections if the preoperative ECG was abnormal, versus nine per cent with normal ECG. The Goldman index was developed in 1977 as a multifactorial predictor for cardiac risk in non-cardiac surgery. ${ }^{15}$ Patients may be divided into four risk classes on the basis of a 0-53 point score. During 1986-1987 157 patients who had pulmonary resections at the Montreal General Hospital were studied prospectively. The Goldman score predicted a low risk (five per cent, 5/97) for the class 1 patients. However, there was no further discrimatory predictive power among the Goldman classes 2,3 or 4 who had a combined cardiac risk of 33 per cent $(20 / 60)$. Cardiomegaly on the chest $x$-ray ${ }^{6}$ or a rightventricular strain pattern on the $\mathrm{ECG}^{16}$ were associated with a particularly high rate of cardiac complications.

\section{Exercise tolerance}

Exercise capacity may be the most specific predictor of post-thoracotomy cardio-respiratory complications. ${ }^{8}$ Patients with a maximum $\mathrm{O}_{2}$ consumption $>20 \mathrm{ml} \cdot \mathrm{kg}^{-1}$ $\mathrm{min}^{-1}$ are extremely unlikely to have complications. Stair climbing is a useful but less objective assessment of cardiorespiratory reserve. Stair climbing capacity correlates with maximum voluntary ventilation, $\mathrm{FEV}_{1}$ and DLco. ${ }^{18}$ A patient who can climb two flights without difficulty can usually tolerate even a pneumonectomy without problem.

\section{Extent of resection}

Morbidity is highest for pneumonectomy, less for lobectomy and still less for segmentectomy or wedge resection. ${ }^{4}$ In patients with peripheral stage 1 carcinomas the five-year survival was not different after lobectomy than after a lesser resection. ${ }^{19}$ Miller $^{20}$ found an acceptable five-year survival of 31 per cent in 31 patients with marked impairment of pulmonary function (e.g., $\mathrm{FEV}_{1}<$ $1.01)$ after wedge resection for non-small cell bronchogenic cancer.

Pneumonectomy, especially right pneumonectomy, is associated with cardiac complications. One study found the incidence of post-pneumonectomy arrythmias was 26 per cent in patients with a previous history of angina, cardiac failure or hypertension; while it was only 2 per cent in others. ${ }^{21}$ Pneumonectomy patients who have an intra-pericardial dissection or develop postoperative pulmonary oedema are also at increased risk for arrythmias. The post-pnumonectomy mortality in another study ${ }^{22}$ was 25 per cent with arrythmias versus 10 per cent in non-arrythmic patients. The commonest important postoperative arrythmia is atrial fibrillation. In view of these risks, and since improving myocardial contractility seems to be an important treatment for sudden increases in right-ventricular afterload ${ }^{23}$ it seems advisable to digitalize perioperatively any pneumonectomy patient with a history of cardiac disease.

\section{Surgical incision}

The use of median sternotomy has been described for lung resection. This incision gave a significant impovement of pulmonary function (in non-resection intrathoracic surgery) on postoperative days 2-4 versus lateral thoracotomy ${ }^{24}$ Urschel ${ }^{25}$ described the successful, routine use of median thoracotomy for all types of lung resections, including 15 patients with preoperative $\mathrm{FEV}_{1}<0.81$ who were deemed to be inoperable by lateral thoracotomy.

Median sternotomy requires mandatory use of onelung ventilation (OLV) and is technically more difficult for some left lower lobe and posterior chest wall lesions. It is extremely useful for simultaneous bilateral resections. ${ }^{26,27}$

\section{Concurrent medical therapy}

Another potential cause of improved outcome is improved preoperative therapy of concurrent medical problems. A large fraction of these patients has chronic obstructive pulmonary disease (COPD). These patients may have bronchospasm, atelectasis and/or infection which require optimal preoperative physical and medical treatment. In particular the anaesthetist should consider:

The regular use of nebulized aerosol $\beta_{2}$-agonists even in the absence of detectable wheezing

Beta ${ }_{2}$-agonists have been shown to be therapeutic, and also prophyllactic in preventing bronchoconstrictive mediator release from mast cells. ${ }^{28}$ 
The additional use of nebulized aerosol ipratropium bromide, a topical atropine-like bronchodilator Ipratropium is long acting, synergistic with $\beta$ - agonists ${ }^{29}$ and particularly effective in COPD ${ }^{30}$ Also, intraoperative bronchospasm may, to large degree, involve parasympathetic reflexes. ${ }^{31}$

Certain susceptible patients develop bronchial hyper-reactivity with left ventricular overload ${ }^{32}$

Fluid overload should be avoided and/or aggressively treated.

In all patients with a malignancy the anaesthetist must consider the " $3 \mathrm{M}$ 's" (mass effects, metabolic abnormalities and metastases). In particular there are a number of paraneoplastic syndromes (Cushings, SIADH, EatonLambert, hypercalcaemia, etc.) associated with lung malignancy that must be evaluated preoperatively.

\section{Intraoperative management}

Monitoring: There have been many recent advances in perioperative monitoring. Among the most important for pulmonary resection surgery are:

\section{Pulse oximetry}

The risk of arterial oxygen desaturation is much higher during lung surgery than most other forms of elective surgery. The availability of an "on-line" assessment of arterial oxygen saturation has improved the intraoperative safety. The anaesthetist must be aware of the reliability and limitations of the particular equipment used ${ }^{33}$ and verify periodically with arterial blood gases.

\section{Invasive arterial pressure}

Surgery around the lung hilum often causes sudden wide swings in systemic blood pressure due to sympathetic stimulation or venous compression. Invasive monitoring simplifies intraoperative management and allows assessment of the postoperative $\mathrm{PaCO}_{2}$.

\section{Expired minute volume}

A ventilator which measures expired minute volume (e.g., Siemens 900 series) is particularly useful in thoracic anaesthesia. A leak from the ventilated to non-ventilated lung via a doublc-lumen tube, or a parenchymal or bronchial air leak will be demonstrated by a decrease in the expired volume.

\section{Expired $\mathrm{CO}_{2}$}

During one-lung ventilation, sudden changes in the ventilation of the dependent lung will be reflected by a change in the capnograph. This is an important early indication of surgical airway compression or tube dis- placement that may otherwise be difficult to diagnose when the patient is in the lateral position.

\section{Intravascular volume}

The central venous pressure (CVP) does not seem to add much useful information in the majority of cases in the lateral position with the thorax open. As in other types of major surgery ${ }^{34}$ if preload information is critical, a pulmonary artery (PA) catheter is more useful. It is quite common for a PA catheter in the non-dependent lung (ND-lung) to become permanently wedged during lung collapse for one-lung ventilation. Falsely low pulmonary capillary wedge pressures (PCWP) can occur after pnemonectomy ${ }^{35}$ or in other situations with an extensive loss of the pulmonary vascular bed. In the majority of lung resections CVP or PA monitoring is not needed.

\section{Fibreoptic bronchoscope (FOB)}

The FOB is a useful monitor to survey the placement of bronchial tubes or blockers. As with any new monitor it will take time until a consensus is reached whether it should be used routinely or only for specific indications. ${ }^{36}$ The criteria for appropriate size and function of a suitable FOB have been described. ${ }^{37}$ The risk/benefit ratio of FOB assessment of double-lumen tube position is so low that I recommend it for all cases involving one-lung ventilation. An appropriate FOB should be available in any institution that has a significant volume of elective pulmonary surgery. Training in the use of the FOB should now be a part of any anaesthetic residency program.

\section{One-lung ventilation (OLV)}

The routine use of OLV for pulmonary resections was first advocated by Jenkins and Clarke ${ }^{38}$ in 1957 and since that time has gradually increased in popularity. Complete acceptance of the routine use of OLV in chest surgery has been delayed by anaesthetists' legitimate concerns regarding intraoperative hypoxaemia, airway trauma and malposition of bronchial tubes or blockers. On the positive side, OLV makes the surgical dissection quicker and easier. In one prospective study of pulmonary surgery with/without OLV: there were no differences in the $\mathrm{PaO}_{2}$ during OLV versus during two-lung ventilation with retraction of the ventilated ND-lung. ${ }^{39}$

Significant airway trauma occurs so rarely that it is difficult to study. Better designed double-lumen tubes ${ }^{40}$ and further studies of their function ${ }^{41}$ should decrease this risk. Increased use of the FOB for direct-vision bronchial intubation in difficult cases should also decrease airway trauma and tube malposition. Better understanding of the pathophysiology of OLV allows us to begin to predict which patients are likely to demonstrate oxygen desatu- 
ration during $\mathrm{OLV}^{42}$ and also allows the improvement of intraoperative techniques to treat and prevent hypoxaemia during OLV. ${ }^{43}$

OLV should be regarded as an anaesthetic technique used to facilitate surgery, similar to such techniques as controlled hypotension or muscle relaxation. OLV can aid in the management of any pulmonary resection and the decision to use OLV should be on the basis of a risk/benefit analysis by the anaesthetist and surgeon.

\section{Endobronchial tubes and blockers}

For the majority of pulmonary resections there is no clear-cut advantage to using either a double-lumen bronchial tube or a bronchial blocker to achieve OLV. A new "Univent" tracheal tube which incorporates a movable bronchial blocker has had positive and negative reviews. ${ }^{44,45} \mathrm{~A}$ new system of co-axial broncho-tracheal intubation has also been described. ${ }^{46}$

The use of double-lumen tubes allows easy and repetitive access to the ND-lung for visualization, suction or oxygenation. In the United States, routine use of double-lumen tubes for thoracic surgery is increasing. Silvay in a hospital survey in 1983 found the minority of anaesthetic departments used double-lumen tubes in $>50$ per cent of pulmonary resections. ${ }^{47}$ When the study repeated in $1988^{48}$ they found that the majority was now using double-lumen tubes for $>50$ per cent of cases. Most reports of tracheobronchial trauma from disposable double-lumen tubes suggest improper size ${ }^{49}$ or overdistention of the bronchial cuff. ${ }^{50}$

Since the left main stem bronchus is longer than the right, the average margin of safety in positioning left double-lumen tubes $(15-20 \mathrm{~mm})$ is greater than that for right-sided tubes $(0-5 \mathrm{~mm}) .{ }^{51}$ Also, the concentric shape of the bronchial cuff on left-sided tubes permits more reliable one-lung isolation at lower bronchial cuff inflation pressures. However, the narrower left main bronchus is anatomically more difficult to intubate. The difficulty of bronchial intubation must be assessed preoperatively by reviewing the chest $x$-ray, CT scan and bronchoscopist's report. In cases with distorted peri-carinal anatomy it is best to intubate the bronchus under direct FOB guidance.

Allthough left-sided double-lumen tubes function well in the majority of left- and right-sided thoracotomies, their use is impossible in certain cases such as left main bronchial surgery. In these a right-sided tube must be used. There are major differences in the design and clinical function of currently available right-sided doublelumen tubes ${ }^{52}$ leading to potential difficulty in achieving one-lung isolation and obstruction of the right upper lobe bronchus.

\section{Intraoperative ventilation}

Dead space ventilation will increase from approximately 0.3 to 0.5 of tidal volume $(V T)$ when the ventilated patient is turned from the supine to the lateral position. The dead space fraction may increase further or decrease with the onset of OLV. A simple method of ventilation is to use a $\mathrm{VT}$ of $10 \mathrm{ml} \cdot \mathrm{kg}^{-1}$ for both two- and one-lung ventilation. A higher $V_{T}$ may encourage more perfusion of the collapsed ND-lung due to increased airway pressure during OLV. A lower VT may encourage dependent-lung atelectasis. ${ }^{53}$

The compliance of the dependent lung will decrease by 20 per cent and the functional residual capacity (FRC) by eight per cent after turning to the lateral position ${ }^{54}$ Once the thorax is open pulmonary mechanics change markedly. The FRC is the balance point between chest wall expansion and lung recoil. Once the thorax is open the ND-lung collapses and thus FRC is meaningless. Similarly the dependent lung will exhale slowly over a prolonged period as the mediastinum settles. With normal ventilation rates, this lung does not usually reach to its new FRC between breaths and a positive end-expiratory flow develops. Positive end-expiratory flow is associated with the development of intrinsic positive end-expiratory pressure (auto-PEEP). The mean level of auto-PEEP measured during routine OLV in a group of ten patients was $6 \mathrm{~cm} \mathrm{H}_{2} \mathrm{O}$ and correlated with the age of the patient. ${ }^{55}$

\section{Lung perfusion}

The major haemodynamic changes occur with turning to the lateral position and an opening the chest. Subsequent initiation of OLV causes little cardiovascular change in most patients. ${ }^{56}$ The venous return decreases in the lateral position and a secondary decrease in CVP, PCWP and cardiac output may follow. OLV causes no significant change in the mean PA pressure in most patients. Clamping the ipsilateral PA causes an average increase of $3 \mathrm{mmHg}$ in the mean PA pressure in pneumonectomies. ${ }^{16}$

OLV will cause the intrapulmonary shunt $\left(Q_{s} / Q_{1}\right)$ to rise from levels of $0.15-0.2$ during two-lung ventilation to $0.3-0.5$ during OLV. There are several mechanisms which limit the increase of $Q_{s} / Q_{t}$ during OLV:

1 The ventilated lung is usually the dependent lung and has a hydrostatic increase in perfusion pressure. The right lung normally receives 55 per cent of the cardiac output. In the lateral position the proportion of perfusion to the dependent lung increases by ten per cent. This will not apply during lung resection via median sternotomy.

2 Hypoxic pulmonary vasoconstriction (HPV) is a reflex which acts at the pulmonary arterioles via a mechanism that seems to involve leukotrienes ${ }^{57}$ to decrease perfusion to hypoxic lung regions. A maximal HPV re- 
sponse decreases regional perfusion by 50 per cent. ${ }^{58}$ HPV functions best during normal homeostasis and large deviations of $\mathrm{PaCO}_{2}, \mathrm{PETCO}_{2}$, PA pressure or mixed venous $\mathrm{PO}_{2}$ cause inhibition. Lung trauma, aspiration, catecholamines and vasodilators also inhibit HPV. The volatile anaesthetics halothane, ${ }^{59}$ enflurane and isoflurane ${ }^{60}$ are mild inhibitors of HPV in clinical doses.

There is no consensus on how important HPV is during OLV. ${ }^{61}$ Clinical studies suggest that volatile anaesthetic agents do not impair oxygenation during OLV. ${ }^{62}$

3 Mechanical factors due to atelectasis may decrease regional perfusion, but this is not clear. ${ }^{63-66}$ These studies have largely been on animal models and extrapolation to the clinical setting is uncertain.

Early studies of OLV suggested that arterial oxygen desaturation occured in $15-20$ per cent $^{67.68}$ of cases. The nadir of the fall in $\mathrm{PaO}_{2}$ occurred 15-30 minutes after the start of OLV. It has been stated that the decrease in $\mathrm{PaO}_{2}$ is unpredictable. ${ }^{69}$ However, in a prospective study (unpublished data) we found that the $\mathrm{PaO}_{2}$ decreased to $<80$ mmh during OLV in only $6 / 80$ (7.5 per cent) of patients. The $\mathrm{PaO}_{2}$ during OLV correlated directly with the $\mathrm{PaO}_{2}$ during two-lung ventilation and inversely with the preoperative FEV , per cent. Also, patients having left-sided thoracotomies had better $\mathrm{PaO}_{2}$ values during OLV than those having right-sided surgery. Patients who had decreased perfusion to the operative lung (ND-lung) on a preoperative $\dot{V} / \dot{Q}$ scan had better $\mathrm{PaO}_{2}$ values during OLV. ${ }^{70,71}$

\section{Treatment of Hypoxaemia during OLV}

There are several methods of treating and/or preventing hypoxaemia during OLV:

\section{Re-expansion of the lung}

Periodic re-inflation of the ND-lung is a reliable treatment for hypoxaemia. ${ }^{72}$ However, this will interfere with surgery.

\section{Obstruction of the ipsilateral pulmonary artery}

This can be done by surgical clamping or a PA balloon. These manoeuvres require surgical manipulation and are generally only feasible during pneumonectomys.

Manipulation of the tidal volume to the dependent lung Patients who have a low $\mathrm{PaO}_{2}$ with a small $V_{\mathrm{T}}(7$ $\left.\mathrm{ml} \cdot \mathrm{kg}^{-1}\right)$ may show improved $\mathrm{PaO}_{2}$ with a larger $\mathrm{VT}(14$ $\left.\mathrm{ml} \cdot \mathrm{kg}^{-1}\right)$ and vice versa. ${ }^{53}$

PEEP to the dependent lung

In the majority of patients this produces a deterioration in
$\mathrm{PaO}_{2} \cdot{ }^{53}$ However, the occasional individual with considerable arterial desaturation improves with PEEP. Studies of $\mathrm{PaO}_{2}$ during OLV with PEEP have not allowed for the probable complex interaction of applied (extrinsic) PEEP with auto-peep. ${ }^{55}$

\section{Continuous positive airway pressure (CPAP) to the $N D$-lung}

This is the most useful single technique. ${ }^{73}$ However, the levels of CPAP should be kept low $\left(2-5 \mathrm{cmH}_{2} \mathrm{O}\right)$ and the lung allowed to deflate partially to give an optimal compromise between $\mathrm{PaO}_{2}$ and surgical exposure. ${ }^{43}$

\section{High frequency ventilation (HFV) of the ND-lung}

This gives excellent $\mathrm{PaO}_{2}$ values during $\mathrm{OLV}$ but causes dilatation of central airways and interferes with the surgical resection. ${ }^{74,75} \mathrm{HFV}$ may be more useful during non-pulmonary thoracic surgery.

\section{Pharmacological manipulations}

Dobutamine $\left(5 \mu \mathrm{g} \cdot \mathrm{kg}^{-1} \mathrm{~min}^{-1}\right)$ can cause an increase in $\mathrm{PaO}_{2}$ during $\mathrm{OLV}$, apparently due to better V/Q matching. ${ }^{76}$ Clinically, I have not found the degree of increase in $\mathrm{PaO}_{2}$ to be useful in those patients who desaturate.

ND-lung CPAP is all that is needed for the majority of patients who demonstrate arterial desaturation during OLV. For refractory patients a combination of the above techniques may be superior to CPAP alone. ${ }^{77}$

\section{Anaesthetic techniques}

Yeager et al. ${ }^{78}$ in a study of high-risk patients, found the combined use of "light" general anaesthesia with epidural anaesthesia/analgesia (EAA) reduced postoperative complications. This would question the popular notion that anaesthetic technique has no influence on outcome. A report of 90 pulmonary resections using EAA described very low morbidity and mortality figures. ${ }^{79}$

During thoracic surgery nitrous oxide is of no benefit. It is contraindicated with bullae or pneumothoraces. It offers less protection against collapse of low V/Q lung regions than $\mathrm{O}_{2}$ alone. ${ }^{80} \mathrm{~N}_{2} \mathrm{O}$ mildly inhibits $\mathrm{HPV}$ and can cause overdistention of an air-filled bronchial cuff. Substitution of air for $\mathrm{N}_{2} \mathrm{O}$ during lung surgery decreases postoperative atelectasis. ${ }^{81}$

It is possible that allowing complete atelectasis of the ND-lung may cause a temporary dysfunction after reexpansion. Re-expansion pulmonary oedema can occur after only several hours of collapse. ${ }^{82}$ In dogs, lung water is less after slow than after fast re-expansion. ${ }^{83} \mathrm{Nevin}^{84}$ found better postoperative $\mathrm{PaO}_{2}$ values and fewer chest infections if the ND-lung was maintained distended with HFV during OLV versus collapse. 


\section{Fluid management}

This has not been well studied for chest surgery. In the absence of extensive chest wall or mediastinal dissection there does not seem to be a large potential "third space" loss. Surgical manipulation of the ND-lung probably interferes with lymphatic flow and the lung's defences against fluid overload are reduced. Dependent lung oedema can also occur, perhaps related to an increased pulmonary capillary pressure in this lung ${ }^{85}$ but not in the collapsed lung. Pulmonary congestion can develop easily with fluid overload in thoracic surgery. ${ }^{86}$ Excessive intraoperative fluid administration correlates with postpneumonectomy pulmonary oedema. ${ }^{21}$

EAA makes it more difficult to avoid fluid overload since these patients tend to be hypotensive. Right ventricular function becomes more important in the setting of decreased preload and a sudden increase in afterload. ${ }^{87}$ This may necessitate more liberal perioperative use of invasive monitoring, vasopressors and inotropes. It should also be noted that perioperative blood transfusion may decrease long-term survival after lung cancer surgery.$^{88}$

\section{Postoperative management}

\section{Respiratory function}

The early recovery of respiratory function after lung surgery has not been carefully studied. Much of what has been written is extrapolated from other types of surgery. The effect of the thoracotomy itself will disappear by six weeks. ${ }^{89}$ The immediate decrease in vital capacity (VC) (40 per cent) is less than after upper abdominal surgery ( 60 per cent). However, the VC will continue to decline after thoracotomy until the third postoperative day. In all other types of surgery the VC rises after the first day. ${ }^{90}$ This may contribute to the high incidence of respiratory complications in the two to four days after surgery.

After pulmonary surgery there is probably a degree of diaphragmatic dysfunction," upper abdominal surgery. ${ }^{92}$ The work of respiration doubles during the first postoperative week. This increased work of breathing must be met by increased chest wall work. For upper abdominal surgery some of what was thought to be diaphragm dysfunction may be related to abnormal abdominal muscle activity. ${ }^{93}$

The FEV , will decrease to $35-45$ per cent of the preoperative value in the immediate postoperative period. ${ }^{94}$ The early loss of pulmonary function is disproportionately high for lobectomies versus pneumonectomies, ${ }^{95}$ but by six weeks the loss of $F E V_{1}$ is in proportion to the amount of lung resected. ${ }^{96}$ Clinically, lobectomy patients tend more toward postoperative respiratory than cardiac complications.

\section{Postoperative analgesia}

Among the many recent innovations are:

\section{Epidural/spinal opioid analgesia}

The incidence of postoperative complications is related to the loss of pulmonary reserve. Epidural analgesia is the only form of post-thoracotomy analgesia consistently shown to improve pulmonary function. In a double-blind study Shulman ${ }^{94}$ showed a significantly greater early recovery of FEV 1 to 67 per cent of preoperative values with epidural morphine versus 44 per cent with parenteral morphine. The expected FEV $V_{1}$ recovery two weeks after a lobectomy is only 63 per cent. ${ }^{97}$ There is at present no consensus on the optimal drug, dosage, route or combination with local anaesthetic.

\section{Intrapleural analgesia}

Although useful in some patients, this has not had the same success rate following thoracic as upper abdominal surgery. It was not found superior to parenteral opioids. ${ }^{98}$

\section{Cryoanalgesia}

Mechanical freezing of the intercostal nerves provides a degree of analgesia, but this was found inferior to epidural fentanyl. ${ }^{99}$ Also, there is some concern regarding the incidence of neuralgia following cyroanalgesia. ${ }^{100}$

\section{Thoracic paravertebral block}

This has been described for analgesia after thoracic trauma ${ }^{101}$ and surgery. ${ }^{102}$ The spread of anaesthetic seems extremely variable. It has not yet been studied in a controlled fashion.

\section{Intercostal local anaesthetic blockade}

Intercostal blockade: single/multiple and intermittant/ continuous is a useful and well known method of postthoracotomy analgesia. ${ }^{103}$ It was not found to be superior to epidural local anaesthetic. ${ }^{104}$

\section{Patient controlled analgesia (PCA)}

Recent advances in pump design have made this a valuable clinical tool. ${ }^{105}$ In patients unsuitable for epidural analgesia, we use a combination of intercostal block and PCA opioid.

\section{Summary}

Management options to consider in the high-risk patient for pulmonary resection include:

1 The use of EAA plus a postoperative pain management scheme to optimize pulmonary function in the critical two to four days after surgery.

2 The use of a "step-down" or intermediate care area, ${ }^{106}$ with a level of monitoring between that of the intensive 
care unit and the regular postoperative ward, for the initial three to four days.

3 Preoperative optimization of concurrent medical conditions with aggressive physical and medical therapy.

4 Careful titration of intra-operative fluids with early recourse to invasive monitoring, vasopressors and inotropes. Perioperative digitalization of patients with a history of cardiovasuclar disease for pneumonectomy.

5 Avoidance of $\mathrm{N}_{2} \mathrm{O}$. Ventilate intraoperatively with an air/oxygen mixture, during both two- and one-lung ventilation, titrated against the arterial oxygen saturation. Avoidance of complete intraoperative atelectasis of the ND-lung with a low level of air/oxygen CPAP.

6 Surgical alternatives. The use of a median sternotomy or limited resection.

A simple cost/benefit analysis tells us that not every recent advance in thoracic anaesthesia is indicated for every patient. It is now part of the anaesthetist's responsibility to identify the high-risk patient and to develop an appropriately stratified management plan.

\section{References}

1 Wahi R, McMurtrey MJ, DeCaro LF et al. Determinants of perioperative morbidity and mortality after pncumonectomy. Ann Thorac Surg 1989; 48: 33-7.

2 Boysen $P G$. Anesthesia for thoracic procedure. Marshall BE (Ed.). Boston: Blackwell scientific publications, 1988, p 169.

3 Drigs $P$. Preoperative assessment of lung cancer. Chest 1989; $96: 42 \mathrm{~s}-44 \mathrm{~s}$.

4 Ginsberg RJ, Hill LD, Eagan RT et al. Modern thirty-day operative mortality for surgical resections in lung cancer. J Thorac Cardiovasc Surg 1983; 86: 654-58.

5 Weiss $W$. Operative mortality and 5 year survival rates in men with bronchogenic carcinoma. Chest 1974; 66: 483-7.

6 Mittman C, Bruderman I. Lung cancer. To operate or not. Am Rev Respir Dis 1977; 116: 477-96.

7 Nakahara K, Mouden Y, Ohno K, Miyoski S, Maeda H, Kawashima $Y$. A method for predicting postoperative lung function and its relation to postoperative complications in patients with lung cancer. Ann Thorac Surg 1985; 39: 260-5.

8 Smith TP, Kinasewitz GT, Tucker WY, Spillers WP, George RB. Exercise capacity as a predictor of post-thoracotomy morbidity. Annual Review Respir Dis 1984; 129: 730-4.

9 Shirakusa T, Tsutsui $M$, Iriki $N$ et al. Results of resection for bronchogenic carcinoma in patients over the age of 80. Thorax 1989; 44: 189-91.

10 Markos J, Mullan BP, Hillman DR et al. Preoperative assessment as a predictor of mortality and morbidity after lung resection. An Rev Respir Dis 1989; 139: 902-10.
II Nakahara K, Ohno K, Hashimoto J et al. Prediction of postoperative respiratory failure in patients undergoing lung resection for lung cancer. Ann Thorac Surg 1988; 46: 549-52.

12 Ferguson $M K$, Little L, Rizzo L et al. Diffusing capacity predicts mobidity and mortality after pulmonary resection. J Thorac Cardiovasc Surg 1988; 96: 894-900.

13 Weruley JA, DeMeester TR, Kirchner PT et al. Clinical value of quantitative ventilation-perfusion lung scans in the surgical management of bronchogenic carcinoma. J Thorac Cardiovasc Surg 1980; 80: 535.

14 Didolkar MS, Moore RH, Taiku H. Evaluation of the risk in pulmonary resection for bronchogenic carcinoma. Ann J Surg 1974; 127: 700

15 Goldman L, Caldera DL, Nussbaum SR et al. Multifactorial index of cardiac risk in noncardiac surgical procedures. New Engl J Med 1977; 297: 845-50.

16 Van Nostrand D, Ejelsberg MO, Humphrey EW. Preresectional evaluation of risk from pneumonectomy. Surg Gynecol Obstet 1968; 127: 306-12.

17 Bechard D, Wetstein L. Assessment of exercise oxygen consumption as preoperative criterion for lung resection. Ann Thorac Surg 1987; 44: 344-9.

18 Bolton JWR, Weiman DS, Haynes $J L$, Hornung $C A$, Olsen $\mathrm{GN}$, Almond $\mathrm{CH}$. Stair climbing as an indicator of pulmonary function. Chest 1987; 92: 783-8.

19 Errett LE, Wilson J, Chiu RCJ, Munro DD. Wedge resection as an alternative procedure for peripheral bronchogenic carcinoma in poor-risk patients. J Thorac Cardiovasc Surg 1985; 90: 656-61.

20 Miller $J$, Hatcher $C R$. Limited resection of bronchogenic carcinoma in the patient with marked impairment of pulmonary function. Ann Thorac Surg 1987; 44: 340-3.

21 Verheijen-Breemhaar L, Boguard JM, Van Den Berg B. Hilvering $C$. Postpneumonectomy pulmonary edema. Thorax 1988; 43: 323-6.

22 Krowka MJ, Pairolero PC, Trastek VF, Payne WS, Bernatz $P E$. Cardiac dysrythmia following pneumonectomy. Chest 1987; 91: 490-5.

23 Prewitt RM, Ghignone $M$. Treatment of right ventricular dysfunction in acute rcspiratory failure. Crit Care Med 1983; 11: 346-52.

24 Cooper JD, Nelems JM, Pearson FG. Extended indications for median stemotomy in patients requiring pulmonary rescction. Ann Thorac Surg 1978; 26: 413-20.

25 Urschel HC, Razzuk MA. Median sternotomy as a standard approach for pulmonary resection. Ann Thorac Surg 1986; 41: 130-4.

26 Johnston $M R$. Median sternotomy for resection of pulmonary metastases. J Thorac Cardiovasc Surg 1983; 85: 516-22.

27 Dalton $M$, Coltharp WH. Simultaneous resection of 
synchronous bilateral bronchogenic carcinoma using median sternotomy. J Thorac Cardiovasc Surg 1987; 94 : 916-8.

28 Holgate ST, Woolcock AJ. (Eds.). Asthma - what are the important experiments? Am Rev Resp Dis 1988; 138: 730-44.

29 Beck R, Robertson C, Goldes-Sebalt M, Levinsault. Combined salbutamol and ipratropium by inhalation in the treatment of severe active asthma. J Pediatr 1985; 107: 605-8.

30 Gorr NJ. Ipratropium Bromide. N Engl J Mcd 1988; 319: 486-94.

31 Shah $M V$, Hirschman CA. Mode of action of halothane on histamine-induced airway constriction in dogs with reactive airways. Anesthesiology 1986; 65: 170-4.

32 Cabanes LR, Weber SN, Matran $R$ et al. Bronchial hyperresponsiveness to methacholine in patients with impaired left ventricular function. New Engl J Med 1989; 320: 1317-22.

33 Severinghans $J W$, Naifeh $K H$. Accuracy of six pulse oximeters to profound hypoxemia. Anesthesiology 1987; 67: $551-8$

34 Ansley DM, Ramsay JG, Whalley DG et al The relationship between central venous pressure and pulmonary capillary wedge pressure during aortic surgery. Can J Anaesth 1987; 34: 594-600.

35 Wittnich C, Trudel J, Zidulka A, Chiu RCJ. Misleading pulmonary wedge pressure after pneumonectomy: its importance in postoperative fluid therapy. Ann Thorac Surg 1986; 42: 192-6.

36 Ehrenwerth J. Pro: proper positioning of a double-lumen tube can only be accomplished with endoscopy. J Cardiothorac Anesth 1988; 2: 101-4.

37 Slinger $P D$. Fibreoptic bronchoscopic positioning of double-lumen tubes. J Cardiothorac Anesth 1989; 3 : 486-96.

38 Jenkins $A V$, Clarke $G$. Endobronchial anaesthesia with the Carlens catheter. Br J Anacsth 1958; 30: 13-8.

39 Thomson DF, Campell $D$ : Changes in arterial oxygen tension during one-lung anacsthesia. $\mathrm{Br} \mathrm{J}$ Anaesth 1973; 45: 611-6.

40 Benumof $J L$. Improving the design and function of double-lumen tubes. J Cardiothorac Anesth 1988; 2: 729-33.

41 Brodsky.JB, Adkins MO, Gaba DM. Bronchial cuff pressures of double-lumen tubes. Anesth Analg 1989; 69: 608-10.

42 Slinger PD, Suissa S, Adam J, Triolet $W$. Predicting arterial oxygenation during one lung ventilation with CPAP to the non-ventilated lung. I Cardiothorac Anesth (in press).

43 Slinger $P D$, Triolet $W$, Wilson J. Improving arterial oxygenation during one-lung ventilation. Anesthesiology 1988; 68: 291-5.

44 MacGillivray $R G$. Evaluation of a new tracheal tube with a movable bronchus blocker. Anacsthesia 1988; 43: 687-9.

45 Karwande SV. A new tube for single lung ventilation. Chest 1987; 92: 761-3.

46 Nazari $S$, Trazzi $R$, Moncalvo F, Zonta A, Campani $M$. Selective bronchial intubation for one lung anacsthesia in thoracic surgery. Anaesthesia 1986; 41: 519-26.

47 Silvay $G$, Eisenkraft JB, Weinreich $A I$. The anesthetic management of pulmonary resection: survey and recommendations. Mt Sinai J Med 1983; 50: 236-7.

48 Silvay $G$, Desiderio $D$, Reich $D L$. (letter). J Cardiothorac Anesth 1988; 2: 119-20.

49 Wagner DL, Gammage G, Wong $M L$. Tracheal rupture following insertion of a disposable double-lumen tube. Anesthesiology 1985; 63: 698-700.

50 Burton NA, Fall SM, Lyons T, Graeber GM. Rupture of the left main-stem bronchus with a polyvinylchloride double-lumen tube. Chest 1983; 83: 928-9.

51 Benumof JL, Partridge BL, Salvatierra C, Keating J. Margin of safcly in positioning modern double-lumen endotracheal tubes. Anesthesiology 1987; 67: 729-38.

52 Slinger $P$, Triolet $W$. A clinical comparison of three different designs of right sided double-lumen tubes. Can J Anaesth 1989; 36: S59.

53 Katz JA, Laverne RG, Fairley $H B$, Thomas AN. Pulmonary oxygen exchange during endobronchial anesthesia, effect of tidal volume and PEEP. Anesthesiology 1982; 56: 164-70.

54 Larsson A, Malmkuist $G$, Werner $O$. Variation in lung volume and compliance during pulmonary surgery. $\mathrm{Br}$ J Anaesth 1987; 59: 585-91.

55 Slinger $P D$, Hickey $D R$, Lenis SG, Gotfired S. Intrinsic PEEP during one-lung ventilation. Anesth Analg 1989; 68: S269.

56 Peltola $K$. Central hemodynamics and oxygenation during thoracic anaesthesia. Acta Anacsthesiol Scand 1983; 275: $1-42$.

57 Marshall C, Kim SD, Marshall BE. The actions of halothane, ibuprofen and BW755C on hypoxic pulmonary vasoconstriction. Anesthesiology 1987; 66: 537-42.

58 Domino $K B$, Borowec $L$, Alexander $C M$ et al. Influence of isoflurane on hypoxic pulmonary vasoconstriction in dogs. Ancsthesiology 1986; 64: 523-9.

59 Bermaes $W$. Hypoxia induced pulmonary vasoconstriction in man: inhibition duc to diethyl ether and halothane ancsthesia. Acta Anacsthesiol Scand 1978; 22: 570-88.

60 Benumof JL, Augustine SD, Gibbons JA. Halothane and 
isoflurane only slightly impair arterial oxygenation during one-lung ventilation in patients undergoing thoracotomy. Anesthesiology 1987; 67: 910-5.

61 Kerr JH. Baillicres Clinical Anesthesiology: Thoracic Anaesthesia. London: Bailliere Tindall, 1987; 1: 69.

62 Rogers $S N$, Benumof $J L$. Haolothane and isoflurane do not decrease $\mathrm{PaO}_{2}$ during one lung ventilation in intravenously anesthetized patients. Anesth Analg 1985; 64: 946-54.

63 Glasser SA, Domino KB, Lindgran L, Parcella P. Marshall $C$, Marshall $B E$. Pulmonary blood pressue and flow during atelectasis in the dog. Anesthesiology 1983; 58: 225-31.

64 Chen L, Williams JJ, Alexander CM, Ray RJ, Marshall C, Marshall $B E$. The effect of pleural pressure on the hypoxic pulmonary vasoconstrictor response in closed chest dogs. Anesth Analg 1988; 67: 763-9.

65 Barer GR, Howard P, MCCurrie JR. Shaw JW. Changes in the pulmonary circulation after bronchial occlusion in anesthetized dogs and cats. Circulation Res 1969; 25: 747-64.

66 Miller FL, Chen L, Malmkvist G, Marshall C, Marshall $B E$. Mechanical factors do not influence blood flow distribution in atelactasis. Anesthesiology 1989; 70: 481-8.

67 Tarhan S, Lundborg RO. Blood gas and $\mathrm{pH}$ studies during use of the Carlens catheter. Can Anaesth Soc J 1968; 15: 458-63.

68 Thomson DF, Campbell $D$. Changes in arterial oxygen tension during one-lung anaesthesia. $\mathrm{Br} \mathrm{J}$ Anaesthesia 1973; 45: 611-6.

69 Nakatsuka $M$, Wetstein $L$, Keenan $R L$. Unilateral highfrequency jet ventilation during onc-lung ventilation for thoracotomy. Ann Thorac Surg 1988; 46: 654-60.

70 Hurford WE, Kolker $A C$, Strauss $H W$. The use of ventilation perfusion lung scans to predict oxygenation during one-lung anesthesia. Anesthesiology 1987; 67: 841-3.

71 Nomoto $Y$. Preoperative pulmonary blood flow and onc-lung anaesthesia. Can J Anacsth 1987; 34: 447-9.

72 Malmkvist $G$. Maintenance of oxygenation during onelung ventilation. Effect of intermittant rcinflation of the collapsed lung with oxygen. Anesth Analg 1989; 68: 763-6.

73 Capan LM, Turndorf H, Patel C, Ramanthan S, Acinapura A, Chalon J. Optimization of arterial oxygenation during one-lung anesthesia. Anesth Analg 1980; 59: 847-51.

74 Glenski JA. Crawford M. Rehder K. High-frequency small-volume ventilation during thoracic surgery. Anesthesiology 1986; 64: $211-4$.

75 Jenkins J. Cameraon EWJ, Milne AC, Hunter RM. Onelung anaesthesia. Cardiovascular and respiratory func- tion compared during conventional ventilation and high-frequency jet ventilation. Anacsthesia 1987; 42 : 938-43.

76 Nomoto $Y$, Kawamura $M$. Pulmonary gas exchange effects by nitroglycerin, dopamine and dobutamine during one-lung ventilation in man. Can J Anaesth 1989; 36 : 273-7.

77 Obara H, Tanaka O, Hoshino Y, Kaetsu H, Maekawa N. Iwai $S$. One-lung ventilation, the effect of positive end-expiratory pressure to the nondependent and dependent lung. Anaesthesia 1986; 41: 1007-10.

78 Yeager MP, Glass DD, Neff RK, Brinek-Johnsen $T$. Epidural anesthesia and analgesia in high-risk surgical patients. Anesthesiology 1987; 66: 729-36.

79 Temeck BK, Schafer PW, Park WY, Harmon JW. Epidural anesthesia in patients undergoing thoracic surgery. Arch Surg 1989; 124: 415-8.

80 Dantzker $D R$, Wagner $P D$, West JB. Instability of lung units with low $V_{A} / Q$ ratios during $\mathrm{O}_{2}$ breathing. J Appl Physiol 1975; 38: 886--95.

81 Browne DRG, Rochford J, O'Connell U, Jones JG. The incidence of postoperative atelectasis in the dependent lung following thoracotomy: the value of added nitrogen. Bi J Anaesth 1970; 42: 340-6.

82 Sherman $S$, Ravikrishnan $P$. Unilateral pulmonary edema following reexpansion of pneumothorax of brief duration. Chest 1980; 77: 714.

83 Ray RJ, Alexander CM, Chen L, Williams J, Marshall $B E$. Influence of the method of re-cxpansion of atelectatic lung upon the development of pulmonary edema in dogs. Crit Care Med 1984; 12: 364-6.

84 Nevin M, Van Besouw JP, Williams CW, Pepper JR. A comparative study of conventional versus high- frequency jet ventilation with relation to the incidence of postoperative morbidity in thoracic surgery. Ann Thorac Surg 1987; 44: 625-7.

85 Sigel LC, Pearl RG, Shafer SL, Ream AK, Prielipp RC. The longitudinal distribution of pulmonary vascular resistance during unilateral hypoxia. Anesthesiology 1989; 70: 527-32.

86 Hutchin P, Terzi RG, Hollandsworth LA, Johnson $G$, Peters RM. . Pulmonary congestion following infusion of large fluid loads in thoracic surgical patients. Ann Thorac Surg 1969; 8: 339-47.

87 Weber KT, Jonicki JS, Shroff SG, Likoff MJ, St. John Sutton $M G$. The right ventricle: physiologic and pathophysiologic considerations. Crit Care Med 1983; 11 : 323-8.

88 Moores DWO, Piantadosi S, McKneally MF. Effect of perioperative blood transfusion on outcome in patients with sugically resected lung cancer. Ann Thorac Surg 1989; 47: 346-51 
89 Gorlin R, Knowles JH, Storey GF, Fletcher HP, Smith $S H$. Effects of thoracotomy on pulmonary function. $J$ Thorac Surg 1957; 34: 242-9.

90 Ali J, Weisel RD, Layug AB, Kripke BJ, Hechtman HB. Consequences of postoperative alterations in respiratory mechanics. Am J Surg 1974; 128: 376-82.

91 Kawashima $Y$. Diaphragm function after pulmonary resection. Am Rev Resp Dis 1988; 137: 678-81.

92 Ford GT, Whitelaw WA, Rosenal TW, Cruse PJ, Guenter $C A$. Diaphragm function after upper abdominal surgery in humans. Am Rev Respir Dis 1983; 127: 431-6.

93 Duggan JE, Drummond GB. Abdominal muscle activity and intraabdominal pressure after upper abdominal surgery. Anesth Analg 1989; 69: 598-603.

94 Shulman M, Sandler AN, Brandley JW, Young PS, Brebner $J$. Postthoracotomy pain and pulmonary function following epidural and systemic morphine. Anesthesiology 1984; 61: 569-75.

95 Ali MK, Mountain CF, Ewer MS, Johnston D, Haynie $T P$. Predicting loss of pulmonary function after pulmonary resection for bronchogenic carcinoma. Chest 1980; 77: 337-42.

96 Berend N, Woolcock AJ, Marline GE. Effects of lobectomy on lung function. Thorax 1980; 35: 140-5.

97 Vrusasco V, Ratto GB, Crimi P, Sacco A, Motia G. Lung function following upper sleeve lobectomy for bronchogenic carcinoma. Scan J Thor Cardiovasc Surg 1988; 22: 73-8

98 Scheinin $B$, Lindgren $L$, Rosenberg $P H$. Treatment of post-thoracotomy pain with intermittant instillations of intrapleural bupivacaine. Acta Anaesthesiol Scand 1989; 33: $156-9$.

99 Gough JD, Williams AB, Vaughan RS. The control of post-thoracotomy pain. A comparative evaluation of thoracic epidural fentanyl infusions and cryo-analgesia. Anaesthesia 1988; 43: 780-3.

100 Fagiano G, Borasio P. Salamino A, Sodero A, Ricci C, Ardissone $F$. Risultatic immediati e a distanza del crio-bloccodei intercostali nel trattamento de dolore post-operatorio in chirurgia toracica. Min Anest 1985; 5I: 39-43.

101 Gilbert J, Hultman J. Thoracic paravertebral block: a mcthod of pain control. Acta Anaesthesiol Scand 1989; 33: 142-5.

102 Canacher ID, Kokri M. Postoperative paravertebral blocks for thoracic surgery. Br J Anaesth 1987; 59: 155-61.

103 Sabanathan S, Smith PJB, Pradhan GN, Hashimi H, Eng $J-B$, Mearns AJ. Continuous intercostal nerve block for pain relief after thoracotomy. Ann Thorac Surg 1988; 46: 425-6.
104 Asantila R, Rosenberg PH, Schenin B. Camparison of different methods of postoperative analgesia after thoracotomy. Acta Anaesthesiol Scand 1986; 30: 421-5.

105 Owen H, Mather LE, Rowley $K$. The development and clinical use of patient-controlled analgesia. Anaesth Intensive Care 1988; 16: 437-47.

106 Byrick RJ, Power JD, Ycas JO, Brown KA. Impact of an intermediate care area on ICU utilization after cardiac surgery. Crit Care Med 1986; 14: 869-72. 